2. A volume containing an account of the physical and chemical observations and investigations, with a special discussion thereon. To this volume will be appended tables of analysis, ta.bles of specific gravities, reports on the microscopical examination of minerals, \&c.

3. A series of volumes, probably not less than six in number, containing a detailed account of the fauna, and plates illustrating the undescribed or imperfectly known forms.

In case of plates being required, the space available for figures on each plate is not more than II by $8 \frac{1}{2}$ inches ( $=28$ by $12^{\circ} 5$ centimetres). It is intended that the plates shall be, generally speaking, in lithograph; but if any form of engraving seem preferable in any case, a special arrangement may be made. Woodcuts will be given where required.

I undertake the editing of the work, and all manuscripts and proofs of plates are to be sent to me.

All packages and letters to be addressed-

$$
\begin{gathered}
\text { Professor Sir Wyville Thomson, F.R.S., } \\
\text { University, } \\
\text { Edinburgh. }
\end{gathered}
$$

and marked "Challenger."

The intention at present is that the preparation of all the volumes shall go on simultaneously, and it is earnestly desired that the different parts may be done as speedily as is consistent with the utmost care and accuracy. Authors are invited to enter into any anatomical or other details which may be desirable for the full illustration of the groups in their hands; and their full consideration is particularly requested of all questions bearing upon geographical distribution, and upon the relation of the deep-sea fauna to the fauna of the later geological periods.

Authors will be at full liberty to publish abstracts of the results of their work during its progress, in the proceedings of Scientific Societies; but such communications should be made through me or with my knowledge, and "by permission of the Lords Commissioners of the Treasury."

I am directed to report to Government and to fumish my accounts at certain intervals; and in order that I may be able to do so, authors are requested to report progress and to render accounts and vouchers for any expenses which they may have incurred, to me quarterly; on or before the Ist of March, of June, of September, and of December.

In the following list of stations-

I. The number is given by which each particular station is referred to throughout. The first eight stations, to which Roman numerals are attached, are to be considered in a certain sense preliminary; the regular series commences with Station I (bis) on the 15 th of February, 1873 , and is indicated by Arabic numbers up to 354

2. The date is given.

3. The exact position of the ship at noon of the day on which the observations were made.

4. The depth in fathoms (=6 English feet).

5. An abbreviation, as it is given on the chart, indicating the nature of the bottom :-

r. (rock) indicates hard ground, where nothing was brought up by the sounding instrument, there being at the same time evidence that the tube had reached the bottom.

m. (mud), a material varying in colour, but derived chiefly from the disintegration of the land.

gl. oz. (globigerina ooze), a white or greyish deposit formed in a great measure of the shells, entire or broken, of foraminifera belonging to the genera Globigerina, Orbulina, Pulvinulina, and Hastigerina, usually with a quantity of amorphous calcareous or earthy matter, and many coccoliths.

di. oz. (diatom ooze) indicates a deposit formed to a great extent of the frustules of diatoms which have sunk from the surface.

rad. oz. (radiolarian ooze) indicates a deposit composed mainly of the skeletons of Polycystina and other Radiolarians.

r. cl. (red clay) indicates a deposit, very widely extended in deep water, of red, reddish, or grey aluminous mud, such as would be produced by the decomposition of a felspathic mineral. This deposit varies considerably in character; it seems to be derived from several sources, but one of the most important of these appears to be the decomposition of pumice and other volcanic products. The "red clay" often contains concretionary nodules, consisting chiefly of the oxides of manganese and iron.

gr. oz. (grey ooze), and gr. m. (grey mud), usually indicate an intermediate condition between Globigerina ooze and red clay, or in some cases a fine-grained grey deposit, formed in deep water, chiefly of land débris.

The positions of the stations are shown on the accompanying chart.

Edinburgh, January 2

\section{PROF. AGASSIZ ON THE "CHALLENGER" COLLECTIONS}

DROF. AGASSIZ, who has come to this country for the express purpose of examining the Challenger Collection, has kindly sent us the following notes on what he has already seen :-

I have seen a great many alcoholic collections of marine animals made by direction of different government expeditions, and in no case have I seen one in a better state of preservation, or where greater care had been taken to insure the accuracy of the locality. Those who work up the material will have the double advantage of working on admirably-preserved collections, and of being absolutely certain of the exact locality of their specimens. Sir Wyville Thomson has already called attention, in his Preliminary Reports to the Royal Society and his Lecture before the British Association at Glasgow, to many of the most interesting things collected, and he has also alluded to the mount of the material brought together. I may perhaps give a better idea of the magnitude of the collections by stating that if a single individual, having the knowledge of the eighteen or twenty specialists into whose hands the collections are to be placed, were to work them up, he would most certainly require from seventy to seventy-five years of hard work to bring out the results which the careful study of the different departments ought to yield.

We may assume that the work of the Challenger has probably accomplished for the depths of the ocean in general what the American and English expeditions of I866-I869 did for the North Atlantic, for it certainly is remarkable how much these expeditions, working over a comparatively limited area, contributed to the knowledge of the deep-sea fauna, and how little of novelty has been added by the subsequent and more extended work of the Challenger over the same ground. Judging from these premises, we may fairly say that hereafter, while any new expedition will undoubtedly clear up many of the points left doubtful by the Challenger, and may carry out special lines of investigation only partly sketched out, yet we can hardly expect them to do more than fill out the grand outlines laid down by the great English expedition.

To attain the best possible results it is of the utmost importance that the collections brought home should be placed in the hands of specialists who are thorough masters of their respective departments. The scientific public will therefore hear with the greatest satisfaction that the Government has left the collections in the hands of Sir Wyville Thomson, who is to direct the publications until the whole of this invaluable material is thoroughly worked out. 